SHS Web of Conferences 6, 01006 (2014)

DOI: $10.1051 /$ shsconf / 20140601006

(C) Owned by the authors, published by EDP Sciences, 2014

\title{
The Rural Cooperative in China under the Governance of the Christ Ethic Value
}

\author{
Wu Xiliang ${ }^{1, \mathrm{a}}$ \\ ${ }^{1}$ Center for Public Policy and Social Management Innovation, Henan Normal University, 453007 \\ Xinxiang Henan, China.
}

\begin{abstract}
Based on the analysis on the basic information, problems and characters of rural cooperative in China, the paper finds that the cooperative governance by the blood, institution should be changed into the governance by civil ethic. We compare the relation between Christ ethic and the rural cooperative in China and find the close relation between them. The cooperation, equality and devotion in cooperatives are also shown in Christ. With the case of the cooperatives found by Chinese Christians, we also find that the belief in China should be of freedom, the traditional ethic should be innovated and the religions could promote the daily public good affairs without the political intervention.
\end{abstract}

Keywords. Christ; Cooperative; Diversity-orderly Structure

\section{Introduction}

Farmers' Specialized Cooperatives (abbreviated as FSC, the main part of the rural cooperatives) develop very quickly in China. But the cooperatives could not work well. Hu Lan, Wang Lei (2009), Chen Guoxiong (2009) pointed out some problems such as the he shortage of funds and talents. The main problem is that many cooperatives lack standards and do not operate according to the national law on FSCs and the principles of ICA.

Why could the good cooperative institution not work well in China? The rural cooperative in China has the same characters of the background society such as the blood family base, politics control and profit orientation. Zhang Kangzhi (2009) studied three kinds of cooperation in three societies. Mutual assistance belongs to agricultural society, coordination belongs to industrial society, and cooperation belongs to post-industrial society. China is in the phrase between agricultural society and industrial society. There are three kinds of cooperatives such as kinship cooperative, institution cooperative and ethic cooperative. The institution is based on the ethic. In China, there are many cooperatives mixed with kinship and the institution of market economy and political ideology. The cooperative institution needs to have the ethic as the foundation.

We try to compare the Christ of the world and Cooperative in China and find that there is a close relation between them.

There are also some scholars who studied the relation between the Christ and Cooperatives based on some cases. E.g., Herrera, David (2004) studied the Mondragon cooperatives and thought that the

a Corresponding author: wuxiliang2008@yahoo.com 
for-profit organization embodied the Catholic social thought. Michael Klein (2009) studied the cooperative work of Friedrich Wilhelm Raiffeisen and thought the root of the cooperatives was Christ. This paper gives the analysis between the Christ of the world and the rural cooperative in China based on the cases in China.

\section{Basic information, problems and characters}

\subsection{Basic information}

Table 1. The development situation of FSCs in China

\begin{tabular}{|c|c|c|c|c|}
\hline Year & $\begin{array}{c}\text { Number of the } \\
\text { FSCs(ten thousand) }\end{array}$ & $\begin{array}{c}\text { Year-on-Year } \\
\text { Growth }\end{array}$ & $\begin{array}{c}\text { Number of Famers } \\
\text { (ten thousand) }\end{array}$ & $\begin{array}{c}\text { Year-on-Year } \\
\text { Growth }\end{array}$ \\
\hline 2007 & 2.67 & & 35 & \\
\hline 2008 & 11.09 & $315.4 \%$ & 1800 & $5042.9 \%$ \\
\hline 2009 & 24.64 & $122.2 \%$ & 2100 & $16.7 \%$ \\
\hline 2010 & 37.91 & $53.9 \%$ & 2900 & $38.1 \%$ \\
\hline 2011 & 53.17 & $37.6 \%$ & 4100 & $41.48 \%$ \\
\hline
\end{tabular}

In China, the main part of the rural Cooperatives is the Farmers' Specialized Cooperatives. According to official statistics, since the Law of the People's Republic of China regarding Farmers' Specialized Cooperatives (FSCs), promulgated in 2006, came into effect on 1 July 2007, there has been a very rapid growth of FSCs. The FSCs numbered more than 379,100 by the end of 2010 and more than 531,700 by the end of 2011. Until the first half of 2012, the registered FSCs numbered 600,000. The average increasing number is 10,000 every month. There are more than 46 millions farmers which joined in the FSCs and the number covers the $18.6 \%$ of all farmers in China. The average member number is about 80 every FSC.

\subsection{Problems}

The FSCs face many problems such as the shortage of funds and talents. The main problem is that many cooperatives lack standards and do not operate according to the national law on FSCs and the principles of ICA. The mechanism governing the distribution mechanism of the FSCs' profits is incomplete, the benefit of the cooperatives' chairmen is not made clear in the law, the FSCs are dominated easily by the big farmers and capable men, the normal members would like to be freeriders and are unable to participate in decision-making and are unwilling to supervise the chairmen; the financial management lacks standards (Hu Lan, Wang Lei 2009). Based on a study of 27 FSCs in Zhanjiang city of Guangdong Province, it was shown that the management of the cooperatives lacked standardization and democracy, the cooperatives were dominated by several stockholders and had few or no second profit return to the members; most FSCs were of small scale and had low-quality personnel, etc. (Chen Guoxiong 2009).

\subsection{Characters}

Chinese rural cooperatives are established on the family blood, controlled by the political communism ideology and affected by Mormonism in the society. 


\subsubsection{Blood--based on the family}

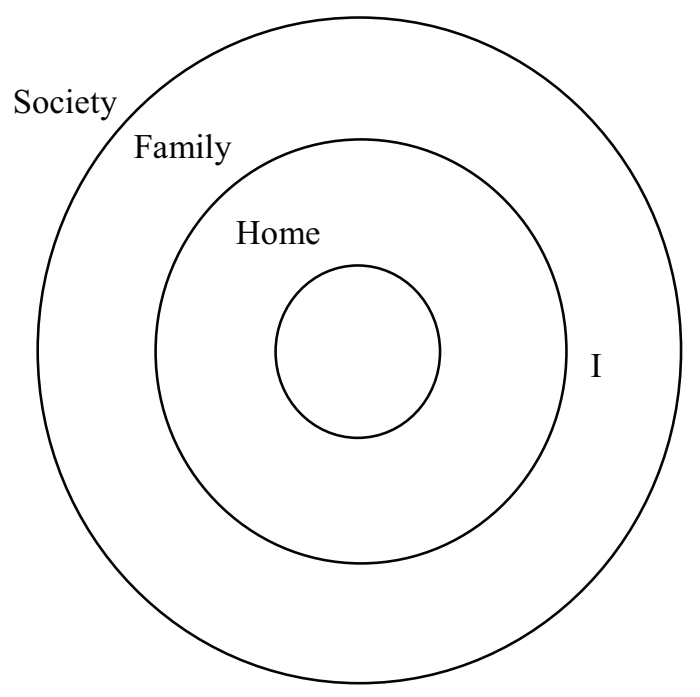

Figure 1. Diversity-orderly structure of Chinese society

Chinese rural cooperatives are small and established on the family blood. The members of the cooperatives are members of the families at the same time. The family members could play a role in developing the cooperatives in the early stage. But the family relations would limit the further development of the cooperatives because the governance of the cooperatives is based on the blood of the families. Only the directly-related family member could be trusted to get the key station in the cooperatives. The relations in the rural China are not equal and Fei Xiaotong (2009) describes the relation as a concentric circle. The core is I, from inside to the outside, the sequence is home, family and society. The member relation in rural cooperatives has the same sequence with the whole society. The cooperatives are affected by the whole social culture. The relations among the members are not equal. Even though the members of cooperatives are members of one family, the directors of the cooperatives tend to have their wives as accountants rather than their brothers.

\subsubsection{Ideology--politics control}

In the last one hundred years, politics took the cooperatives as a tool to implement the principles of People's Livelihood of the Three People's Principles (Nationalism, Democracy, and People's Livelihood) in the period of China Republic and Communism in the early period of People's Republic of China. The cooperatives had a close tie with politics. Sun Zhongshan promoted cooperatives to restrict capitalism. Mao Zedong used cooperatives to unite the scattered farmers in the rural areas to meet the need in the city. After the foundation of the People's Republic of China, many kinds of cooperatives such as the Supply and Marking Cooperative, the Handcraft Industry Cooperatives lost their original volunteerism and became the departments of the governments. Many agricultural cooperatives were merged together as People's Communities. The cooperatives were politicized and administrativized

Politics was never stable and it affected the life of the people and civil cooperatives. After the death of Mao Zedong in 1976, Deng Xiaopeng came to power and cancelled the Peoples' communities. The farmers' lands were contracted to farmers by household for the efficiency. Then farmers began the small-scale family-based farming and China faced the problems how to socialize the small-scale farmers again. In the 1980s, some agricultural Science \& Technology associations or agricultural industry associations were established to solve the small-scale farming problems. National 
Law of FSCs was implemented in July, 2007 and a lot of FSCs were developed. But how to improve the management level of the FSCs is the key problem to make the FSCs develop healthily.

Even today, politics affects the whole society. The CPC has more than 80 million members and the party is a huge organization which administrates the government, the congress, public security organs, etc. At the same time, the ideology of the party controls the press, the newspaper and magazines. In rural China, the CPC controls all the farmers' organizations through establishing the branches in them. Even today, many CPC branches have been established in FSCs. For example, after some pilot experiments, the Fengxian District government of Shanghai City has promoted party construction of FSCs since October, 2010. Until September 2012, 24 CPC branches, 20 joint branches, 104 groups were established and 108 Party construction instructors were selected to help 360 FSCs. The party construction work has covered all the cooperatives in this district (Hu Yurong 2012). The party organizations are extended where economy develops.

The party uses the simplex politics ideology mind to guide the cooperatives and so controls the mind of rural cooperatives. Then the rural cooperatives are taken as political achievement by the CPC and by the government. It is difficult to have other ideas as the direction of the cooperative spirit. The politics belief has been taken as the belief of the civil belief and the idea of the cooperatives. When politics has a powerful position, also the cooperatives are powerful; but cooperatives would collapse if politics fails. The past People's Community taught us a useful lesson. So many today's empty shell cooperatives have some relations with the politics control. The governments would like to develop as many cooperatives as possible, which would be taken as the achievement of CPC and government, even though most of the FSCs cannot work well.

In China, the political ideology invades too much, and it even takes the place of the civil ethic and belief. The cooperation idea of the civil voluntary cooperatives needs the support of the civil belief and ethic.

\subsubsection{Mammonism --profit orientation}

Since the 1980s, the economy reform has been going on in China. The profitable organizations are emphasized more than the non-profitable organizations. There are strict limits to establish a nonprofitable organization.

In rural China, FSCs are taken as a profitable enterprise by farmers. Farmers cannot differentiate the cooperatives and companies. It is not necessary for the farmers to pay the number fees to the cooperatives. The farmers cannot get the profit return from the cooperatives. The traditional buy-sell relation still exists between the farmers and cooperatives.

Communism broke all traditional civil ethics and politics took the place of traditional morals. Politics controlled the people's mind and thus people have a vacuum of belief. With the reforming and opening-up in the $1980 \mathrm{~s}$, the mammonism became more and more popular. So the cooperative was used by some people as a form to apply for the project funds given by the government. It is thought as a normal situation by farmers that the directors of the cooperatives establish the cooperatives and could occupy the whole project funds.

\section{Ethic governance of the cooperatives from blood, institution}

\subsection{Three kinds of cooperation in three societies}

There are three types of cooperation in three societies as stated as Zhang Kangzhi (2009):

- Mutual assistance in agricultural society: Mutual assistance is a primitive cooperation based on family blood ties and ties with fellow townsmen.

- Coordination in industrial society: In industrial society, the various management methods including Taylor's scientific management and Weber's bureaucracy are designed to manage staffs and organizations. 
- Cooperation in post-industrial society: In post-industrial society, network management replaces scientific management and bureaucracy and is implemented in the cooperation organizations which are based on cooperation and include cooperatives, associations, and stakeholders' corporations.

\subsection{Three kinds of cooperatives}

In relation to the three kinds of cooperation in three societies, there are three kinds of cooperatives:

- Kinship Cooperative: the Kinship Cooperatives are established on the blood family in agriculture society. The family members play a role at the beginning of the cooperatives. But when the cooperatives grow, the blood family government cannot meet the requirements of the further development.

- Institution cooperative: The institution cooperative is indulged in the concrete institution design. Nowadays, many technologies and tools about management are introduced to China. The cooperatives tend to choose the management institution of business as the management method of the cooperatives. The cooperative institution is a good, but it needs the background of the civil morals to support it.

- Ethic cooperative: the Ethic cooperative is established on the civil ethic. The regulations of the cooperatives are obeyed by the members and the cooperative is organized voluntarily.

\subsection{Present situation of rural cooperatives in China}

China is developing into an industry society. But the rural areas are still an agricultural society. So the rural cooperatives in China are in a status of development, between the agricultural society and industrial society. Chinese rural cooperatives are still based on the blood family relations and try to have the modern enterprise institutions under the background of special politics institutions to govern themselves. Most of the present rural cooperatives are kinship cooperatives and the cooperative management is guided to a modern business institution with the influence of political ideology. In the future, the real challenge will be how to use the civil ethic to govern the cooperatives as the root of the institutions.

\section{The blend between Christ Ethic and the rural cooperative in China}

This part presents an analysis of the cooperatives based on the comparison between Christianity and Chinese culture.

\subsection{Christianity in China}

The first documented case of Christianity entering China was in the 7th century, which is known from the Nestorian Stele, a stone tablet created in the 8th century. It records that Christians reached the Tang dynasty capital Xian in 635 and were allowed to establish places of worship and to propagate their faith (Ding Wang 2006). During a time of great political and economic unrest, Emperor Wuzong decreed that Buddhism, Christianity, and Zoroastrianism were banned, and their very considerable assets forfeited to the state. Manichaeism tried to enter China again and Roman Catholics also began to be spread in China during the Yuan Dynasty and the Ming Dynasty. But the governments of the Yuan dynasty and the Ming dynasty decreed that Manichaeism and Christianity were illegal and heterodox.

In the last 200 years, Christianity entered China again and gained influence. The missionaries brought technology to China and used it to preach the Christian belief. Christians established the first modern clinics and hospitals in China (Gulick, Edward V. 1975), and provided the first modern 
training for nurses. Both Roman Catholics and Protestants founded numerous educational institutions from the primary to the university level in China.

The period from 1911 to 1949 (Republic China), was signed by the freedom of religious belief. Sun Yat-sen, the founder of Republic China, was a Christ and he compromised the Christian idea and the national ideology, that is to say, the Three People's Principles (Nationalism, Democracy, and the People's Livelihood). After the foundation of the People's Republic of China, religion was discouraged by the state and western Christian missionaries left the country. The Chinese Protestant church entered the communist era having made significant progress toward self-support and selfgovernment. From 1966 to 1976, during the Cultural Revolution, the expression of religious life in China was effectively banned, including even the Three-Self Patriotic Movement (TSPM). The growth of the Chinese house church movement during this period was a result of all Chinese Christian worship being driven underground for fear of persecution. To counter this growing trend of "unregistered meetings", in 1979 the government officially restored the TSPM after thirteen years of non-existence (Johnstone, Patrick 2001) and in 1980 the China Christian Council was formed.

The number of Christians is estimated about 120-140 million by some scholars. However, it is not known exactly how many Chinese Christians there are. Estimated Christian population are difficult to obtain in China because of Christians unwillingness to reveal their belief, the hostility of the national government towards some Christian sects, and because of the difficulties in obtaining accurate statistics on house churches. It seems clear that the number is increasing (John Micklethwait, Adrian Wooldridge 2009).

\subsection{Blend between Christ and cooperation principles}

\subsubsection{Cooperation-righteousness in christ is shown as cooperation spirit in the cooperatives}

In comparison with Christian society in western country, Chinese society is a family-based society, which has been governed by Confucianism for more than two thousand years. More than two thousand years ago, almost in the same period of Jesus, Confucius travelled with his disciples to many states in order to advise the kings in their governance. Confucius' ideas was accepted by the feudal rulers and evolved into "three cardinal guides" and the "five constant virtues" specified in the feudal moral conducts. The "Three Cardinal Guides" are: the ruler guides the subject, the father guides his son, and the husband guides his wife. The "Five Constant Virtues" include benevolence, righteousness, propriety, knowledge and sincerity. Further, the whole set of courtesies guide the five relations between ruler and subject, father and son, brother and brother, husband and wife, friend and friend.

The religion had a close relation with the citizen and social life, but Chinese society had no religion and Chinese people had no social life (Liang Shuming 2005). Confucianism had too many relations with the office and was not considered a religion. It was promulgated mainly among the intellectuals and officials in ancient China. If a commoner wanted to become an officer; he had to spend many years studying the Confucianism for the imperial civil service examinations.

Liang Shuming (2005) thought it was necessary to have another relation between individuals and groups besides Chinese traditional five relations, According to the opinion of Lin Zhiping (2005), Chinese traditional ethics strangers should need other types of relation besides the five relations and the new relation should be righteous in Christ.

The family organization based on patriarchal blood is the basic structure of the agriculture country. A whole set of courtesies in agriculture society is based on families. To expand the relation outside the family, blood was put into a wine cup and drunken with the wine. The new brother relation among strangers was formed through blood. The righteous in Christ is called Yi in Chinese. But in Chinese, Yi have more meanings regarding chivalry and loyalty in a narrow circle, which is very different to the $\mathrm{Yi}$ in Christ. The Yi in Christ means righteous opponent to sin. The cooperation is one form of the righteous in Christ. In Christ there is a pure cooperation, but in the human world it is difficult to have a pure cooperation even though the pureness of the cooperation is $99.999 \ldots \%$. Because human beings are also marked by sin, they cannot have the perfect righteous and cooperation. 


\subsubsection{Equality--the christ family breaks the human family and patriarchal system in the cooperatives}

According to Christianity, there are two different families which belong to Christ or to the human. People are very different in external appearance such as races, languages, ages, etc. and there is also the social stratum in the human family, but they are brothers or sisters and are all considered equal within the Christ family. The Christ family could break the blood family and the social stratum in the cooperatives and build on love and righteous. Christ can break the difference in the human world and all the people are brothers and sisters in Christ' eyes.

\subsubsection{Devotion--the righteous in Christ make the directors willing to devote in the cooperatives}

In order to break the blood family and the money relations within the human family and govern the cooperatives, it is necessary to establish the Christ family with the values of righteous, love, cooperation and equality. Christ is stationed in the cooperatives and never deviates from the cooperation path. Because the ownership of the cooperative is dispersed, in contrast to free riders problems of normal members, the directors tend to control the cooperative leadership. The directors have a key role in the cooperatives. The cooperatives serve the members and are non-profitable to the members. In the beginning of a cooperative establishment, the directors have to devote more to the cooperative than normal members. In Christ, the leaders devote more in this human world and they will be rewarded more in paradise. In the Bible, Jesus washed the feet of his disciples and gave a good example how the leaders should serve his staff. In the western Christianity monotheist culture, God serves the people. In the Chinese polytheist culture, which is melt with Confucianism, Daoism and Buddha, people serve the false God and tend to worship idols.

\section{Cases}

In the western world, there are some cooperatives which have even been influenced by Christ, such as early-timed Mondragon cooperative found by the Catholic priest José Maria Arizmendiarrieta and the Raiffeisein cooperatives established by Christian Friedrich Wilhelm Raiffeisen. The Christians tried to use the cooperatives to establish the ideal economy organizations which conform to the purpose that God made man. Here follow some cases of cooperatives organized by Christians in China.

\subsection{Caleb agricultural mechanization specialized cooperatives}

The Caleb Agricultural Mechanization Specialized Cooperative (CAMSC) was founded by a Christian group in July, 2010, in Panjin city, in the Liaoning Province. The Christians in the church helped each other during the busy farming season. It cost them only three months to finish the construction of the main part of the church in 1993. They had a construction team with more than ten farmers and contacted some construction projects later.

After the development of 18 years, the construction team with more than ten farmers evolved into a cooperative with more than one hundred members. By July, 2010, The Caleb Agricultural Mechanization Specialized Cooperative was established. The cooperative contacted and planted more than $4000 \mathrm{mu}$ of organic paddy fields.

Christians use the cooperative form to produce healthy food and glorify God. In China, the smallscaled farmers always use a lot of chemical fertilizers and pesticides on the farmland. In recent years, many food matters happened in China, such as melamine scandal in 2008, the poisonous chives event in the Shandong Province in 2010. To make people have healthy and ecological rice, the Caleb people contacted and farmed the $4000 \mathrm{mu}$ paddy fields without the use of any chemical fertilizer and pesticide. 
Though the CAMSC was registered as a FSC, the members (also Christians) work voluntarily and the output is distributed according to the needs of the members. The members show more cooperation spirit with the Christian Communism. Max Weber said "The only desire of a true Christian is to be the tool of the Lord, he will find his own dignity because this is his desire, so he would become the beneficial tool of rational transformation and control this world" (Max Weber, 2008). The cooperative form was used by the CAMSC to realize the society of "having all things in common" in the Acts chapter of the Holy Bible (Holy Bible 1989, 211).

\subsection{Some cooperatives established and supported among the Christians in Linyi City, Shandong Province}

In recent years, some cooperatives have been encouraged and supported by the National Committee of Three-Self Patriotic Movement of the Protestant Churches and China Christian Council (National TSPM \& CCC) in Linyi city, Shandong Province, China.

\section{Conclusions}

Though the numbers of the cooperatives led by Christians are few, this kind of cooperative is a good example of how the Christians take the cooperatives as the way of glorying the God and so affect the whole society. We also used some samples to analyze the relations between Christians and Cooperatives to show how the ethic affects the cooperative.

In China, the autonomy of the cooperatives is built on the blood family relations. The heteronomy is the modern enterprise institutions under the background of the simplex politics institution. But the cooperative idea cannot blend the traditional Chinese culture, its market economy, and its political institutions. It is very important to free the belief in China, and to distinguish the political ideology and the civil belief.

We do not refuse the institutions, but we would like to find the ethic source of the institutions. The source of the cooperative institutions has some relation with Christianity in the western world. The next step to make the Chinese cooperatives develop healthily is to renew the institution soil and innovate the Chinese culture. The cooperatives need the corresponding cooperative soil in China.

The cooperative could have the civil belief such as Christianity as its guidance. Of course, Chinese people could have the universal civilization which surpasses Christianity and western universal values such as freedom, democracy and equality. At the same time, the traditional Confucianism could be innovated as new Confucianism which would not only be promulgated among intellectuals and officers, but also among the commoner.

\section{References}

1. Chen Guoxiong, 2009, "Problems and Policy Suggestions In the Development Of The Farmers' Specialized Cooperatives Based on the Investigation To 27 Farmers' Specialized Cooperatives in Zhan Jiang City", South China Finance, 11, pp. 64-65.

2. Ding, Wang, 2006, "Remnants Of Christianity From Chinese Central Asia In Medieval Ages". In Malek, Roman; Hofrichter, Peter (Editors). Jingjiao: The Church of the East in China and Central Asia. Steyler Verlagsbuchhandlung Gmbh.

3. Fei Xiaotong. 2009. Fei Xiaotong Complete Works(Vol. 2). Huhhot: Inner Mongolia People Publishing House.pp.68

4. Gulick, Edward V. 1975. Peter Parker and the Opening of China. Journal of the American Oriental Society, Vol. 95, No. 3 (Jul. - Sep.).pp. 561-562

5. Herrera, David, 2004, Mondragon: A For-Profit Organization That Embodies Catholic Social Thought. Http://www.entrepreneur.com/tradejournals/article/print/116926710.html

6. Holy Bible (New Revised Standard Version), 1989, pp. 211. 
7. Hu Yurong, 2012, Where Economic Develops, Where the Party Organizations are extended. Labor Newspaper. September, 10.

8. John Micklethwait, Adrian Wooldridge. 2009. God is back: How the Global Rise of Faith is changing the World. Allen Lane.

9. Johnstone, Patrick.2001. Operation World. London: Paternoster. pp.164

10. Liang Shuming.2005. Liang Shuming's Complete Works (Vol.1). Jinan: Shandong Press. pp.395

11. Michael Klein, 2009.The Cooperative Work of Friedrich Wilhelm Raiffeisen and Its Christian Roots. IRU-Courier.

12. Zhang Kangzhi, 2008, Concept and Vision Of The Administration Ethics, Beijing: China Renmin University Publishing House, pp. 251-25 